\title{
Food sovereignty and consumer sovereignty: Two antagonistic goals?
}

Cristian Timmermann, Georges F. Félix and Pablo Tittonell

cristian.timmermann@gmail.com

This is a "post-print" accepted manuscript, which has been published in:

"Agroecology and Sustainable Food Systems"

This version is distributed under the Creative Commons Attribution 3.0 Netherlands License, which permits unrestricted use, distribution, and reproduction, in any medium, provided the original work is properly cited.

Please cite this publication as follows:

Timmermann, Cristian, Georges F. Félix and Pablo Tittonell (2018), Food sovereignty and consumer sovereignty: two antagonistic goals? Agroecology and Sustainable Food Systems 42(3): 274-298

The final publication is available at Taylor \& Francis via:

https://doi.org/10.1080/21683565.2017.1359807 


\title{
Food sovereignty and consumer sovereignty: Two antagonistic goals?
}

\author{
Cristian Timmermann ${ }^{1,2}$, Georges F. Félix ${ }^{3}$, and Pablo Tittonell ${ }^{4}$ \\ ${ }^{1}$ Department for Management of Science and Technology Development, Ton Duc Thang University, Ho Chi Minh City, Vietnam \\ ${ }^{2}$ Faculty of Social Sciences and Humanities, Ton Duc Thang University, Ho Chi Minh City, Vietnam \\ ${ }^{3}$ Farming Systems Ecology Group, Wageningen University, Wageningen, The Netherlands; \\ ${ }^{4}$ Natural Resources and Environment Program, Instituto Nacional de Tecnología Agropecuaria, Bariloche, Argentina
}

\begin{abstract}
The concept of food sovereignty is becoming an element of everyday parlance in development politics and food justice advocacy. Yet to successfully achieve food sovereignty, the demands within this movement have to be compatible with the way people are pursuing consumer sovereignty and vice versa. The aim of this article is to examine the different sets of demands that the two ideals of sovereignty bring about, analyze in how far these different demands can stand in constructive relations with each other, and explain why consumers have to adjust their food choices to seasonal production variability to promote food sovereignty and so secure future autonomy.
\end{abstract}

Keywords: Food justice, global justice, right to food, sustainable agriculture, sustainable consumption

\section{Introduction}

In 1996, farmers' organizations from around the world gathered to discuss today's challenges in safeguarding a socially and environmentally sustainable form of food production. The outcome of this gathering was the Declaration on Food Sovereignty (Via Campesina 1996). A preliminary list of demands to progressively achieve food sovereignty was drafted with the aim to revise and adapt this list as social needs, environmental factors, and technological capacities change, embracing from early on the idea that food sovereignty is a dynamic concept that changes over time (Consulta de los Pueblos Indígenas sobre el Derecho a la Alimentación 2002; Nyéléni Forum for Food Sovereignty 2007). An important element incorporated in the later revisions of the concept are principles related to consumer sovereignty. Yet particularly in times where food production has been gradually moving from a supply to a demand-driven scenario (Korthals 2001), the incorporation of this additional element may bring significant challenges for food sovereignty. The aim of this article is to examine how these two notions of sovereignty relate to each other and analyze if these targets can be aimed at simultaneously. We proceed by first introducing some preliminary remarks on food and consumer sovereignty; second, discuss nine central demands within the food sovereignty movement and their relation to consumer 
sovereignty; and third, review the synergies and conflictive issues between the two different sovereignty aims.

\section{Food production and consumer demands}

Food choices are particularly relevant for ethical decision-making as they are generally made on a daily basis and are unavoidable (Korthals 2004; Thompson 2015a). In a world with over 7 billion inhabitants, improving food policies and production pathways at local scales can have an enormously positive effect on nature, on today's people and future generations, and on people in one's community as well as on those living in other parts of the globe (Dar and Laxmipathi Gowda 2013; Godfray et al. 2010; Grey and Patel 2015). Moreover, continued food availability reduces stress, anxiety and fears, improving social relationships and freeing time, and energy to undertake other tasks (Ziegler 2011).

Despite living in a world that produces sufficient food to feed its inhabitants, ${ }^{1}$ hunger is endemic in many regions (Lappé et al. 2013). The environmental footprint of conventional agriculture is having a very detrimental effect on ecosystems (McIntyre et al. 2009; Tittonell 2013). It has become clear that we need major reforms in the food production sector (Frison 2016). Yet to implement such strong reforms, we are in need of effective political institutions that have the will and authority to implement changes. Unfortunately, and with very few exceptions (e.g., Brazil's Zero Hunger Program, see Paes-Sousa and Vaitsman 2014), foodrelated institutions are currently not having sufficient power or will to solve these issues (UNCTAD 2013). While we recognize that States are responsible to secure the human right to adequate food (UN Committee 1999), we are also aware that the inefficiencies of current governmental actions will have to be countered by civil society movements in order to alleviate the worst consequences of State failure. Independent of how, and if, governments assume responsibilities, we welcome food and consumer policies that empower citizens. An empowered citizen, be it a farmer or a mere consumer, has the ability to take independent action to alleviate some of the most grave food-related social problems of our time, something that has intrinsic value on its own. Moreover, and especially important for liberal societies, the strong demand for sovereignty as consumers and food producers reveals that there is a strong desire for selfdetermination, something that should not be ignored in policy-making. We hypothesize that independent actions toward sovereignty should stand in constructive relations with efforts made in other regions and should be able to be pursued in smaller modules or scales according to local environmental and social capacities, opportunities and constraints. In order to allow for progressive realization, food sovereignty and consumer sovereignty will have to constitute a set of single-standing but interconnected demands that can be gradually implemented.

A short note regarding the two main stakeholder groups we refer to: food consumers and food producers. As food consumers, we generally have those people in mind who consume what other people produce. We refer to food producers as a very broad category, from subsistence farmers to industrial farmers, yet a large part of our argument focuses on those who produce food for others.

To examine how the two notions of sovereignty relate to each other and analyze if these two targets can be aimed at simultaneously, we proceed by considering the following aspects. There is no universally accepted list of demands that can be said to be representative for

\footnotetext{
${ }^{1}$ While current global per capita food production averages $2870 \mathrm{Kcal}$ a day (FAO 2015), annual needs for humans range between $1800-2500 \mathrm{KCal}$ a day, according to age, environment and body constitution.
} 
consumer sovereignty, although some interpreters plea for a freedom of consumption and perfect competition (Hansen and Schrader 1997). The case is different with food sovereignty; here we can observe a much wider consensus in accepting the list drafted by La Vía Campesina and its subsequent revisions as the norm (Beuchelt and Virchow 2012; Lee 2013; Shattuck, Schiavoni, and VanGelder 2015). We, therefore, single out the main demands of food sovereignty and deduce by analogy the corresponding demands that consumer sovereignty would entail. The identified demands of consumer sovereignty are complemented by additional insights gathered from political philosophy and the ethical consumerism literature.

The demands we discuss have been identified and synthesized from two of the most prominent declarations on food sovereignty, the above-mentioned declaration of 1996 and the declaration drafted during a later gathering in 2007 (Nyéléni Forum for Food Sovereignty 2007). For the purpose of our argument, we translated the identified demands as (i) right to food, (ii) capacity building, (iii) right to information, (iv) right to access and control the means of production, (v) self-determination, (vi) justice in transactions, (vii) long-term sustainability, (viii) recognition, and (ix) improvement of rural infrastructures (Table 1). We proceed by examining the interaction between these two sets of demands.

Table 1: Overview of the demands for sovereignty

\begin{tabular}{|l|l|l|}
\hline Demands & Food sovereignty & Consumer sovereignty \\
\hline Right to food & Human beings need a continuous supply of adequate food. \\
\hline Capacity-building & $\begin{array}{l}\text { Producers need to improve production, } \\
\text { sales networks, organization } \\
\text { capabilities and information literacy }\end{array}$ & $\begin{array}{l}\text { Consumers need to improve } \\
\text { information literacy and organization } \\
\text { capabilities to secure bargaining } \\
\text { power }\end{array}$ \\
\hline Right to information & $\begin{array}{l}\text { Producers want access to adequate } \\
\text { information to stay competitive and } \\
\text { make better choices }\end{array}$ & $\begin{array}{l}\text { Consumers want to make choices } \\
\text { based on adequate information }\end{array}$ \\
\hline Right to access and control the & $\begin{array}{l}\text { Producers need to access and control a } \\
\text { variety of tangible and intangible } \\
\text { resources to generate food }\end{array}$ & $\begin{array}{l}\text { Consumers need to access and control } \\
\text { the means of production to create } \\
\text { resources that can be exchanged in the }\end{array}$ \\
\hline
\end{tabular}




\begin{tabular}{|c|c|c|}
\hline & & market \\
\hline Self-determination & $\begin{array}{l}\text { Producers want to decide on how to } \\
\text { produce food }\end{array}$ & $\begin{array}{l}\text { Consumers want to exercise autonomy } \\
\text { in the markets }\end{array}$ \\
\hline Justice in transactions & $\begin{array}{l}\text { Producers want to receive adequate } \\
\text { remuneration }\end{array}$ & $\begin{array}{l}\text { Consumers want to receive an } \\
\text { adequate product for their money }\end{array}$ \\
\hline Long-term sustainability & $\begin{array}{l}\text { Producers want to maintain future } \\
\text { food production capacity }\end{array}$ & $\begin{array}{l}\text { Consumers want to be able to } \\
\text { consume products in the future that } \\
\text { are at least as good as the present ones }\end{array}$ \\
\hline Recognition & $\begin{array}{l}\text { Producers want to be recognized for } \\
\text { their efforts and vital role in sustaining } \\
\text { life }\end{array}$ & $\begin{array}{l}\text { Consumers want to be recognized as } \\
\text { agents that are capable of making } \\
\text { informed decisions }\end{array}$ \\
\hline $\begin{array}{l}\text { Improvement of rural } \\
\text { infrastructure }\end{array}$ & $\begin{array}{l}\text { Rural populations do not want to be } \\
\text { deprived of the benefits of modern life }\end{array}$ & $\begin{array}{l}\text { Consumers want to have choice } \\
\text { wherever they live }\end{array}$ \\
\hline
\end{tabular}

\section{First demand: Right to food}

In its most elementary form, a food production system has to provide sufficient food. Yet this does not mean that we should increase production at all costs and in every region. The world produces more food than it needs to feed its human population, but many people cannot access this stock because they lack the financial resources to do so (Wittman et al. 2017). Therefore, production needs to increase in regions where it is currently in short supply to facilitate food entitlement (Tittonell et al. 2016). Currently, more than half of the people in the world who suffer hunger are rural people (World Food Program 2015) who could produce the food they need if empowered and given the means of production (see demands 2 to 5). The food sovereignty movement is not about securing food needs by redistributing oversupplies, but more about empowering people to produce their own food (Thompson 2015b).

The human rights discourse defends a right to adequate food. In the United Nations,' General Comment on the Right to Food, the delegates recognize that for food to be adequate it needs to (i) be sustainable, (ii) cover dietary needs, taking into consideration the different necessities and vulnerabilities for each life cycle, gender, and occupation, as well as the special needs of childbearing, (iii) be free from adverse and toxic substances, and (iv) satisfy cultural or consumer acceptability, leaving room to judge food on non-nutrient-based values (UN 
Committee 1999). Adequacy in this discourse depends on social, economic, cultural, climatic, and environmental factors. States are responsible for securing the conditions where all people have adequate access to food (idem).

People may lack access to food not only because they are poor, but due to the general unavailability and inaccessibility of food in their area. Among the main elements that impede continuous access, other than the lack of resources, we find distance and violence, impeding the utilization, production, and delivery of food. Increasingly we can observe a strong reduction of food assortment in stores located in some urban and rural areas, particularly regarding the availability of fresh vegetables and fruits in the Global North and transition economies (Dixon 2014; Smith 2016). In the Global South, we can observe a similar phenomenon in areas where agriculture is mainly oriented toward the production of cash crops, such as coffee, tobacco, soya, oil palm, and cotton, reducing the availability of land, water, and labor to cultivate crops for local food needs (Ruf, Schroth, and Doffangui 2015; Wittman et al. 2017). Such areas are commonly referred to as food deserts, depicting the difficulty people have in maintaining a well-balanced diet (Howlett, Davis, and Burton 2015; Loo 2014). As these food deserts are mostly located in socially marginalized areas, the insufficient access to quality food contributes to the perpetuation of inequality due to the strong link between unsuitable nutrition with poor health and deficient educational outcomes (Szende 2015).

Violence, and the threat thereof, is another major factor disrupting people's ability to access adequate food. Entire regions and groups suffer from war, oppression by criminal organizations, systemic police and military aggression, massive violence against women, and the normalization of violence as a conflictive resolution method (Messer 2009). Food sovereignty advocates have, therefore, included the freedom from violence among their central demands (Nyéléni Forum for Food Sovereignty 2007).

Lastly, foodstuff that is culturally adequate may be ecologically inadequate (Delgado Ramos 2013). It is urgent to discuss what an adequate diet may entail to feed socially and ecologically responsible products to over 7 billion people (Rundgren 2016; Tittonell 2013). Consumers have to redirect their food demands toward a diet that can be covered by sustainable food systems.

\section{Second demand: Capacity building}

Capacity building is a crucial element to progressively gain sovereignty. As humans, we are not born as political beings and have to learn the necessary skills to interact constructively with others, especially when we are dependent on market transactions to cover food needs. Similarly, food producers require both tacit and scientific knowledge to engage in socially and environmentally constructive relations.

Consumers need to understand a variety of issues related to food policies, food production, sustainable consumption, and nutritional requirements to be able to exercise informed consent. In addition, they need to have sufficient understanding of collective action problems and the potential of consumer organization to be able to exert pressure as a group and thus gain bargaining power (Hassanein 2003). Nowadays consumers can use a variety of social media tools, Internet resources, and communication channels to mobilize, inform, and exert pressure as groups to countervail the power of food retailers. Basic knowledge in politics, business administration, and law can help consumers learn about the potential of group action, the perils of fragmentation, legal measures to exercise rights, funding sources to build 
organizations, and alternative sales strategies that allow to bypass exploitative retailers (Iles and Marsh 2012; Larsen and Lawson 2013; McIvor and Hale 2015).

Capacity building that teaches consumers how to make effective use of local foodstuffs, harvest times, cooking devices, kitchen utensils, and preparation methods can help consumers save money on food and energy as well as reduce wastage. Consumers who have some knowledge on sustainable consumption can tighten the gap between food producers and themselves by adjusting their consumption to the seasonal food supply and help to close food systems by adequately disposing waste. Currently only $1-6 \%$ of food waste that is collected in developing countries is composted (Thi, Kumar, and Lin 2015).

On the food producer side, capacity building is even more complex. The more a farmer wants to be able to produce her own inputs, improve harvest yields, reduce waste, and increase labor efficiency, the more she requires tacit and technical knowledge (Timmermann and Félix 2015). Agroecology fosters a farming method strongly embraced by food sovereignty advocates (Nyéléni Forum 2015); it heavily relies on knowledge that local people have on their surrounding environment, resulting in a more efficient management of natural resources. Knowledge gained through observation of ecosystem processes and dynamics is of crucial value to design sustainable food production systems (De Wit and Iles 2016; Martínez-Torres and Rosset 2014). An agroecological approach promotes the provision of ecosystem services through the implementation of stepwise modifications, which include (1) to make more efficient use of available external inputs, (2) to substitute external inputs by self-produced alternatives, and (3) to redesign the farming system as a whole by integrating all farm components (Gliessman 2002; Sarandón and Flores 2014). A sustainable food system requires ultimately gaining control of distribution channels for one's harvest by developing and maintaining alternative sales models (Iles and Marsh 2012). This may require to (re)establish farmers' cooperatives to achieve economies of scale (McIvor and Hale 2015). When communities, through individual action of both producers and consumers, achieve an integrated food value chain that is driven by a conscious demand based on fair exchanges and does not jeopardize the ability of future generations to feed themselves, we can start to call a food system sustainable.

In times where agricultural inputs become inaccessible or unaffordable, capacity building plays a crucial role in regaining food sovereignty. The "agroecological revolution" triggered by the sudden shortage of external inputs in Cuba is an often cited example on how family farms, supported by governmental food policies and institutions, were able to maintain production despite resource limitations (Altieri et al. 1999; Funes-Monzote, Altieri, and Rosset 2009). Farmers had to reinvent their means of production to adapt to the limited availability of inputs and redesign food production sites toward self-sufficiency. Farmers who acquire the skills to produce their own inputs and diversify their produce become less vulnerable to outside pressures and market fluctuations (Dumont et al. 2016; Schipanski et al. 2016). This knowledge is becoming vital in many parts of the world. As consumers cannot pay higher prices on food due to decreasing wages, it becomes even more difficult for local farmers to afford external agricultural inputs, leading to malnutrition, even in countries with a strong agricultural tradition that were food sufficient some decades ago, as we see in Greece (Konstantinidis 2016). Puerto Rico, facing a similar struggle, is attempting to regain food sovereignty through civil society efforts to support local agriculture and a new generation of farmers using sustainable methods (Holt-Giménez 2013; LeBrón 2016).

Capacity building has an effect on the supply and demand of food products. When people learn how to manufacture the goods they need, or become aware of the environmental and social 
impacts the production of the goods they consume have, they gain the freedom to adapt their consumption, and production methods to better reflect their values. Depending on the resources available, rate of poverty, personal and communal values, and enthusiasm, people may follow alternative methods of production, either by concentrating in providing goods to the markets or by farming for increased self-consumption.

Lastly, capacity building has to occur at all levels, from associations at the community level to larger international organizations. When there is too big of a discrepancy between the capabilities of the different organizations, it will likely occur that only the stronger organizations will succeed at implementing their agendas, increasing existing inequalities (De Grammont 2008; Kalfagianni 2014).

\section{Third demand: Right to information}

The ability to make informed decisions requires a right to access relevant information and information literacy. Access to information can help farmers improve productivity, avoid risks, reduce waste, and ensure quality. Consumers need access to information to make informed decisions on the ethical and cultural acceptability of food, to support sustainable agriculture and to make healthy and environmentally friendly food choices (Beekman 2008; Tencati and Zsolnai 2012).

Information literacy allows the making of better decisions on which crops to harvest, when to do so, and how to combat pests and fertilize soils adequately (Jellema, Meijninger, and Addison 2015). Another advantage is that data can also help farmers use agricultural inputs more efficiently and thus reduce spill offs to non-target crops and the environment (Gebbers and Adamchuk 2010). Food processors and retailers that have extensive information on their food supply chain can trace more effectively the origin of health hazards and issue earlier reliable product recalls and warnings (Coff, Korthals, and Barling 2008). Farmers with adequate information could demand compensation, or at least recognition, for the ecosystem services they provide for society (Power 2010), or if they suspect negative consequences from their activities, they could either change their production processes or prepare for fines they might be liable to pay.

As information literacy increases, whole communities can gain significantly by learning to effectively share and produce information (De Wit and Iles 2016). Today's information technologies, such as the Internet and cell phones, are becoming crucial assets in the quest of improving production, avoiding food poisoning, and halting the propagation of agricultural pathogens. Smartphone applications are continuously emerging to support decision-making in farming and food retail operations (Dehnen-Schmutz et al. 2016). In Kerala, India, wireless communication improved the welfare of fishermen communities. Since cell phone technology was introduced in 1997 profits increased by $8 \%$ while prices for consumers decreased by $4 \%$ (Jensen 2007; Rehman et al. 2013).

Sovereign consumers need access to information to make informed food choices to avoid unethically produced foodstuffs, health hazards, unfair prices, and culturally inappropriate food (Del Savio and Schmietow 2013; Gjerris, Gamborg, and Saxe 2016; Larsen and Lawson 2013). Yet adequate access to food information is still not a reality. A number of countries face enormous hurdles to implement legislation on food labeling, in particular regarding food containing genetically modified organisms (GMOs). Regardless of the position taken on judging the ethical acceptability of GMOs, securing the ability to make an informed decision based on 
nutritional and non-nutritional values is of key importance for consumer sovereignty (Burgess and Walsh 1999). In contrast, farmers who engage in agroecological practices, providing ecosystem services and reducing the negative externalities of food production, have better chances to sell their produce at fairer prices when consumers are aware of the social and environmental costs of conventional agriculture (Dumont et al. 2016; Fridell 2009; Hassoun 2015).

As a concern for social justice, we have to note that the failure to successfully analyze sufficient information might come at the cost of losing competitiveness. Consumer organizations that do not harvest data effectively may risk being overrun by organizations that are better equipped to handle information. As more data becomes available, the competitive advantage gained by those with greater ability to use this resource increases, augmenting inequality (Johnson 2014).

Living in an era of big data is very demanding for both consumers and food producers. Freedom of choice comes at the cost of having to digest large amounts of information to avoid harming others with one's poor choices. Sovereignty comes by definition at the price of not being able to transfer the making of most decisions to others.

\section{Fourth demand: Right to access and control the means of production}

On the consumer side, having access to and control over the means of production could be interpreted as having the right to build one's own business or engage in decent employed work. Shared households need to properly address gender justice to share revenues from market activities with those involved in reproductive or care work. Workers should be adequately remunerated to engage in market transactions, allowing choice regarding where and what to buy.

For farmers, a right to access and control the means of production requires lifting barriers, distributing goods, and redistributing through reforms.

The lifting of barriers is necessary to allow access to intangible goods, such as information and educational resources, whose importance we discussed in the preceding sections. Barriers that require the use intermediaries to access markets need to be removed; farmers need to be taught how to overcome bureaucratic hurdles and address sanitary regulations to commercialize independently their produce. Those offering certifications (e.g., for fair trade or organic products) have to simplify their regulatory apparatus and incentives schemes to not overburden smallholders.

Goods that are renewable (or reproducible), such as seeds, livestock, and agriculturally relevant bacteria and insects, need to be distributed to farmers and continuously exchanged to maintain biodiversity. Tools to save and renew resources have to be distributed. Sustainability demands also major capacity-building efforts to teach people how to save, renew and make resources available, to effectively use and repair tools, and to build fair and effective resource management institutions (Timmermann and Robaey 2016; Tittonell 2016). The need to distribute improved and diverse seeds is urgent, as crops are embedded in a dynamic ecosystem that constantly changes, adding new biotic, and abiotic pressures to existing plant varieties (Gliessman 2007). This forces the farmer to continuously innovate and adapt by introducing new varieties and rearranging existing varieties on the farm (Kloppenburg 2014).

The distribution of resources that are of limited availability, such as land and water, requires major policy reforms. Sustainable resource use and governance demand a series of collective tasks, such as good stewardship, developing novel farming systems, recycling and 
cleaning waters, and undertaking measures to recover and gain new arable land. Land and water resources, however, are limited, calling for major redistributive measures that will find fierce opposition, in terms of land reform (Borras, Franco, and Suárez 2015; Rosset 2009) and new water governance rules (Kallhoff 2014). The production of sufficient food for growing populations requires a systematic recovery of degraded agricultural land, the development of new areas by expanding coastal landfills and irrigating land in deserts, and reducing land-use changes in peri-urban areas.

The rapid urbanization raises major challenges for food sovereignty and demands a number of technological and social innovations to allow and stimulate food production in cities (Bernstein 2014). People willing to produce food in cities should be encouraged and empowered, requiring policy innovations (Rydin et al. 2012). Concretely, urban agriculture requires to develop and distribute specially suited equipment, seeds, and animals for urban environments and to facilitate access to production sites and local markets, for example, through municipal land law reforms that allows the use of empty allotments (Turner, Henryks, and Pearson 2011). Furthermore, extension services are needed to provide training, feedback and solutions to urban farmers, and analyze and collect observations made in urban farming environments to optimize food production (Altieri and Toledo 2011). Much more cooperation from food consumers is needed to reintegrate valuable organic matter and minerals from food residues back into the food chain by composting and reorienting drainage systems to collect more rainwater for food production (Thi, Kumar, and Lin 2015).

At least for what access to the means of production concerns, we can say that consumer and food sovereignty complement each other. When food producers and non-food producers are being productive, both parties are able to exchange their oversupply of resources in the markets.

\section{Fifth demand: Self-determination}

The most fundamental demand of sovereignty is to gain self-determination. For this, both consumers and food producers have to achieve a certain level of empowerment. Here, some conceptual clarification is needed. The concept of self-determination is closely linked to the idea of autonomy. In its most essential form, autonomy is defined as the ability to give oneself rules and regulate one's conduct independent of manipulative or distortional outside forces (Christman 2015). When people seek self-determination as a group they want to be able to take decisions autonomously and have the right to implement these decisions. Food sovereignty advocates favor open deliberation and democratic processes that include all affected members without discrimination in decision-making (Menser 2008; Nyéléni Forum for Food Sovereignty 2007). Under empowerment, we generally understand the acquisition of necessary skills and abilities, and the freedom to use these capabilities (de-Shalit 2004). Yet neither concept implies that people have to be able to do what they want whenever they please. Under a Kantian interpretation of autonomy, we may choose to surrender certain liberties (such as the freedom to harm others) to ensure peaceful coexistence and retain our future ability to exercise reason. Generally, this understanding of autonomy has a strong future orientation. One's action should be a reasonable guide to be engaged as general laws. Simply said, if everyone follows the same action, we should be still able to coexist peacefully and not block our chances to secure our basic needs in the days to come. Yet it is unclear in how far Kant's famous categorical imperative has to take into account consequences in the distant future. We have not set ourselves the task to contribute to Kantian exegesis, and thus will just settle in remarking that one should considerably 
limit one's current freedom in order to make sure one maintains food production capacities in the future and this as self-imposed rule. To live within nature's boundaries is a prerequisite to maintain our cognitive capacities, and thus moral reasoning, functioning, which according to Kant is a wide duty (Rivera 2006). Our actions today should not jeopardize our ability to feed ourselves in upcoming days, as food is a basic need.

To exercise autonomy within food systems, consumers need to build networks and advocacy groups to exert pressure on major food producers and retailers. Advocacy groups will need to be able to define and quantify their demands and identify at what level they are being met (Iles 2005) and when information is being manipulated. Exercising self-determination is becoming increasingly dependent on political literacy.

The capacity to defend interests as a group has also the potential to secure labor rights and environmental protection measures. If single countries deviate and offer lower standards, we can observe a so-called race to the bottom. Competition motivates countries to offer laxer labor laws (Kates 2015) and lower environmental protection standards (Hassoun 2009). To respect the environment cannot be only a local matter as it may harm outsiders (Shebaya 2009).

To secure autonomy in a world dominated by free market principles, where many Northern countries have a highly subsidized agricultural sector, declarations on food sovereignty have demanded the right to protect their markets against food dumping and food imports that do not reflect true production prices (Nyéléni Forum for Food Sovereignty 2007). The declaration also demands a right to prohibit the introduction of genetically modified organisms, partly to protect traditional landraces from genetic contamination, to avoid farmers becoming indebted and as a choice based on shared communal values (idem).

The way self-determination can be exercised will depend much on the level of autonomy people seek as political entities. There is still much debate on this issue, as sovereignty can be aimed as a group, community, peoples, or state (Edelman 2014; Hospes 2014). Fortunately, the fact that we all share the basic need for food obliges us to find a common agreement on food policies that do not leave us in a position of extreme dependency that could ultimately jeopardize freedoms we currently enjoy.

\section{Sixth demand: Justice in transactions}

On both the consumer and producer sides, we can observe a demand for justice in transactions. Trade should be voluntary and based on informed decisions, it should not cause harm and those involved should receive a fair share of revenues (Walton 2014). Wages should allow buying the products one needs for a standard of living that corresponds to one's daily efforts.

Farmers are receiving an increasingly smaller share of the final retail price. Agricultural inputs become steadily more expensive and the share food retailers demand is becoming larger (McIntyre et al. 2009). A number of civil society organizations are condemning this trend. We can find an increasing demand for products that incorporate the principles of justice in transaction in the fair trade movement, demanding that work be fairly remunerated, that workplaces meet minimum safety standards and be free from physical, psychological, and sexual violence and harassment (Raynolds 2014; Fridell 2009). Work should be sustainable in the sense that it can be carried out for a prolonged time without causing major health hazards (Food Ethics Council 2010; Nyéléni Forum 2015). Violence and harassment in workplaces has to be tackled with adequate labor protection laws and agencies that watch that these rights are enforced, especially recognizing the vulnerability of undocumented migrant workers (Loo 2014). 
Buying essential goods such as food should not contribute to maintaining and extending an exploitative system. It is, therefore, crucial that food sovereignty efforts do not lead to a twotier system where the rich get to consume food that is socially and environmentally sustainable, while the poor continue to consume, and thus sustain, food that is produced in an unacceptable manner. People will have to fight as citizens and food consumers for fairer wages that do not oblige them to always choose for the cheapest products, as such food choices will most likely undermine efforts to secure food sovereignty.

\section{Seventh demand: Long-term sustainability}

A food system that embraces long-term sustainability should be sufficiently resilient to absorb stresses to guarantee food security not only for today's people, but for all those to come. Despite this basic principle being self-evident, it has not triggered food policies that truly embrace longterm sustainability. We examine the sustainability of food systems by discussing three widely used categories (Werkheiser and Piso 2015): social, economic, and ecological sustainability.

Socially sustainable. Insufficient access to quality food has enormous detrimental consequences for society. When production falls, the population does not absorb food scarcity evenly; it is usually the poor that pay the price with hunger. Famine causes suffering and pushes people to do things they will never do if they had enough to eat. In severe cases of hunger people have murdered, extorted, used violence, prostitute or enslaved themselves or their children, and accepted other types of demeaning treatment, among many other awful actions (Messer 2009). It is hard to restore social harmony after an episode that has obliged people to change so drastically their behavior.

Malnutrition raises a number of deep social problems too. Malnutrition may cause permanent disabilities and hinders full bodily and cognitive development, especially when suffered at an early age (Ziegler 2011). People who do not eat adequately are more prone to suffer contagious diseases and develop disorders (De Schutter 2011; Friel and Ford 2015). This causes a vicious circle. Poor people cannot afford quality food, thus falling sick, and while being sick are less able to work and afford quality food, thereby further increasing their exposure to diseases.

Social sustainability also demands that food production does not involve unacceptable labor standards. In many regions of the world, the agricultural sector is strongly dependent upon a massive migrating labor force that is often not documented and is not protected by labor laws (Medland 2016; Oxfam America 2004; Underhill et al. 2016). Major efforts have to be made to eradicate exploitative child labor, enforce labor protection law, and reduce unnecessary hardship in agricultural work.

Consumers have a right to make socially sustainable food choices, even if they are poor, which takes us to the next point.

Economically sustainable. Sustainable food systems should be fair for both producers and consumers, making harvests produced in socially and environmentally sustainable ways available at a fair price. Working people should be able to afford such sustainable foodstuffs, and people who do not find employment, are retired, or are unable to work should be supported by governmental programs that secure sufficient incomes to afford these products. 
Financial compensation has to be provided to those who provide valuable services for society, and removed from those who engage in socially and ecologically unsustainable food production. Consumers need to know the true price of what they consume, including multiple subsidies for fossil fuels and animal products, and the price paid for repairing environmental damages (Del Savio and Schmietow 2013).

To avoid hunger, food prices should not have such enormous fluctuations. Particularly net food importing countries facing currency devaluations place their poor population in vulnerable situations, as they can hardly absorb price shocks due to their low incomes (Schipanski et al. 2016).

Ecologically sustainable. As a minimum, we should defend ecological sustainability to sustain ecosystem services that secure humanity's future ability to grow food and sustain human life (Leff 1986; Lessmann and Rauschmayer 2013). To do so we need to (i) reduce wastage and unsustainable consumption (Macfadyen et al. 2015), (ii) reduce the environmental footprint of agriculture, (iii) reduce the load of toxins in the food chain and environment, and (iv) recycle and reincorporate water and nutrients in the production chain (Delgado Ramos 2013). Reducing climate change and animal suffering are strong incentives to shift toward plant-based diets or at least decrease the consumption of animal products. A ridiculous amount of vegetables and fruits are discarded for cosmetic reasons (Devin and Richards 2016). As consumers we need to opt for local foodstuffs and as producers lower the dependence on external inputs that have to be transported and need massive amounts of fossil fuels to be produced (Tittonell 2013). In principle, all farmers are in a position to apply techniques that work toward largely self-sufficient farming systems (Altieri 2002; Méndez, Bacon, and Cohen 2013). This is not the case, however, as few multinationals thrive on selling toxins and other inputs to farmers. For consumers, this represents an opportunity to support producers into shifting toward low-external input production styles (Tencati and Zsolnai 2012; Van Der Ploeg 2014).

\section{Eighth demand: Recognition}

Essential for social recognition is treating people as autonomous beings who are able to make their own judgment free from paternalistic interventions and are capable to change their behavior. This calls for major changes in current practices, in particular, the treatment of women and indigenous people, and the perception of traditional knowledge and methods.

For consumers, recognition also means to be recognized for having special needs. People move through different stages of dependency through their lives, during lactation, childhood, sickness, and old age, others have temporary special needs, as in pregnancy, or continuous special needs due to a disorder or disability. Justice demands that we give these differences due recognition (Gilson 2015).

For food producers, recognition demands understanding each group's special needs, historical struggles, and vulnerabilities, thus securing an environment that enables peaceful coexistence (Beyranevand 2012), particularly the right to follow ecological principles in agriculture. Those incorporating agroecological principles on their farms have to be recognized for the value of their ecosystem services, such as sequestering carbon and conserving biodiversity (Altieri et al. 2015; Coolsaet 2015; Timmermann and Félix 2015).

Indigenous people have to be recognized for their enormous current and historical role in the development of sustainable agriculture and seed varieties (Toledo and Barrera-Bassols 2008). 
These peoples should not be discriminated in decision-making, the distribution of financial and technical assistance for entrepreneurs and long-term development programs. Past injustices these groups have suffered need to be recognized by society at large.

An issue that is highly pervasive is the need to address gender justice, in particular recognizing the role of women in food production and preparation, and the conservation of agrobiodiversity (Agarwal 2014; Shiva 2009). Discrimination against women is deeply anchored in society and, therefore, a variety of rectification measures are required to ensure women gain equality of opportunity and are given due recognition for their current and past role as food producers.

Lastly, aiming at sovereignty is incompatible with paternalistic and patriarchal policies that do not involve all interested stakeholders in a deliberative process. People who have benefited from being in a privileged group need to recognize and accept the importance of policies that are being implemented to address past and present injustices.

\section{Ninth demand: Improving rural infrastructure}

Producing food is not the only goal of agriculture; rural livelihoods need to be improved, ensuring better access to education, health services, transportation, markets, recreational, and cultural activities (Rosset 2009). Poor rural infrastructure continuously prompts farmers to move to the cities. Many farmers do not want their children to continue to be farmers as they do not see a bright future in the countryside (Agarwal 2014).

From a consumer sovereignty side, we could assert that choice in rural areas needs to be diversified. This would call for improvements in roads and distribution channels to be able to access a wider array of products.

Revitalizing rural infrastructure requires implementing typically urban elements of selffulfillment such as scientific and cultural activities, cafés and restaurants, sports centers, and political institutions. However, improving rural infrastructure will be a major challenge as urbanization increases. Cities need a massive amount of resources that are taken from rural areas. Workers migrate to cities where they usually receive higher salaries. Larger cities are absorbing water supplies of adjacent rural areas endangering the livelihoods of farmers (Paré 2010). It will take a considerable change of mind-set among urban dwellers to not see the countryside as an inexhaustible resources tap, but as an area where people are living who supply essential resources and ecosystem services without which urban life would not be possible.

\section{Conflictive issues between the two calls for sovereignty}

A call for sovereignty comes with a strong want for rights. Yet, establishing a sustainable food production system requires a prolonged transition time and continuous commitment. A sovereign food production system secures future rights but comes at the price of renouncing certain liberties in the present.

For example, the initial conversion from a conventional farm to an agroecological and diversified farm may take from 3 to 5 years (Nicholls, Altieri, and Vazquez 2016). While the loss of liberties is immediate, the full benefits of a sustainable and self-sufficient food system comes at a later stage. System redesign often includes labor intensive modifications, such as the intensification of ecological infrastructures (hedgerows, rotations, and insect habitats). The period of conversion or transition may render trade-offs at the farm level, which may include 
productivity and labor gaps. Whereas such conversion processes can be time, money, and resources consuming, a return of investment is only perceived once the ecological infrastructures actually start rendering services in terms of enhanced nutrient cycling, increased pest regulation and improved water use efficiency. Until that system finds an equilibrium, which occurs after the need for external inputs has been significantly reduced, consumers will not be able to enjoy the true benefits of a fully functioning ecological farm.

The understanding of autonomy food producers and consumers have to adopt to attain food sovereignty is markedly different than what the everyday usage of the word suggests. The self-determination of food choices and farming methods has to have a strong future orientation for sovereignty to be possible. More sovereignty implies less dependence on external inputs, suggesting the need for stronger empowerment or decentralized control over the food system (Martínez-Torres and Rosset 2014), targets that encounter fierce opposition from some very strong multinational corporations.

There is a strong need to coordinate individual actions as producers and consumers. These actions have to be embedded in a wider food system and be receptive of social and environmental needs and constraints, calling for a reduction of wastage, adapting consumption to production variations, and re-integrating useful residues in the food production cycles. It is unclear that single groups of people, all pursuing sovereignty autonomously, will generate a collaborative attitude where people set aside their differences to establish a sovereign and sustainable food system.

\section{Synergies between the two calls for sovereignty}

When targeting two distinct though potentially complementary goals, such as food and consumer sovereignty, awareness of the conflictive issues becomes a key factor for increasing cooperation between the two parties. A widespread desire to access information concerning current social and ecological challenges of food production and demand, as well as willingness to acquire the necessary capacities for change, are crucial to secure a sustainable food production system.

A more informed and skilled consumer has the power to reduce waste by adapting consumption to seasonal variations. By recognizing the effort involved in farming and acquiring information on the farm gate prices and retailers' earnings, consumers will be incentivized to purchase their produce more directly so that farmers get a fairer reward for their work.

Farmers can also gather additional capital by providing direct services to urban dwellers in rural areas. A short holiday on a farm may provide sufficient insights on the realities of food production and the needs of rural areas to remunerate such efforts more fairly and to adapt consumption patterns. A trip to the countryside can also foster awareness on how the different farming styles are affecting the ecosystem, thus increasing the motivation to lobby for policies that incentivize sustainable farming methods and tax producers whose farming methods cause significant damages.

Table 2: Examples of possible synergies and conflicts between both types of sovereignty 


\begin{tabular}{|c|c|c|}
\hline Food sovereignty demands & $\begin{array}{l}\text { Synergies with consumer } \\
\text { sovereignty }\end{array}$ & $\begin{array}{l}\text { Conflictive issues with consumer } \\
\text { sovereignty }\end{array}$ \\
\hline Right to food & $\begin{array}{l}\text { Common necessity: everyone needs } \\
\text { adequate food }\end{array}$ & $\begin{array}{l}\text { Consumers may have very } \\
\text { unsustainable food wants (e.g. } \\
\text { strawberries in winter) }\end{array}$ \\
\hline Capacity-building & $\begin{array}{l}\text { Educated consumers will have more } \\
\text { skills to adapt food preparation to } \\
\text { seasonal variations }\end{array}$ & $\begin{array}{l}\text { Capacity-building needs to be } \\
\text { directed to improve the } \\
\text { sustainability of food systems }\end{array}$ \\
\hline Right to information & $\begin{array}{l}\text { An informed consumer knows how } \\
\text { to consume responsibly and reduce } \\
\text { waste (e.g. adapting to seasons and } \\
\text { composting) }\end{array}$ & $\begin{array}{l}\text { Consumers may choose to ignore } \\
\text { awful information to keep enjoying } \\
\text { unethical food habits (e.g. child } \\
\text { slavery in cacao plantations) }\end{array}$ \\
\hline $\begin{array}{l}\text { Right to access and control the } \\
\text { means of production }\end{array}$ & $\begin{array}{l}\text { Consumers who have access to the } \\
\text { means of production can engage in } \\
\text { market transactions }\end{array}$ & $\begin{array}{l}\text { Increased urbanization requires } \\
\text { consumer participation to make } \\
\text { some means of production (e.g. } \\
\text { compost, rainwater) more widely } \\
\text { available }\end{array}$ \\
\hline Self-determination & $\begin{array}{l}\text { Human beings have generally a } \\
\text { desire for autonomy }\end{array}$ & $\begin{array}{l}\text { Consumers and producers may } \\
\text { adopt an understanding of autonomy } \\
\text { that is not compatible with } \\
\text { sustainability }\end{array}$ \\
\hline
\end{tabular}




\begin{tabular}{|c|c|c|}
\hline Justice in transactions & $\begin{array}{l}\text { Well-organized consumer groups } \\
\text { can reduce the sales share by } \\
\text { minimizing the interference of food } \\
\text { retailers and optimizing producer } \\
\text { income }\end{array}$ & $\begin{array}{l}\text { Unfair transactions may take place } \\
\text { when consumers favour cheapness } \\
\text { over quality or ethically-produced } \\
\text { food }\end{array}$ \\
\hline Long-term sustainability & $\begin{array}{l}\text { A solid understanding of global } \\
\text { issues in food production will help } \\
\text { prevent a social and environmental } \\
\text { "race to the bottom" }\end{array}$ & $\begin{array}{l}\text { Single consumers may optimize } \\
\text { their financial resources by opting } \\
\text { for cheaper unsustainable } \\
\text { alternatives }\end{array}$ \\
\hline Recognition & $\begin{array}{l}\text { Effective and efficient } \\
\text { communication leads to wider social } \\
\text { recognition }\end{array}$ & $\begin{array}{l}\text { Discrimination against rural } \\
\text { population is deeply rooted in } \\
\text { privileged social groups }\end{array}$ \\
\hline $\begin{array}{l}\text { Improvement of rural } \\
\text { infrastructure }\end{array}$ & $\begin{array}{l}\text { Rural landscapes with good } \\
\text { infrastructures can be a comfortable } \\
\text { escape place for urban dwellers }\end{array}$ & $\begin{array}{l}\text { Urban consumers may have little or } \\
\text { no incentives to support rural } \\
\text { livelihoods, nor to give up privileges } \\
\text { in favour of rural populations }\end{array}$ \\
\hline
\end{tabular}

\section{Concluding remarks}

In principle, people can aim for food sovereignty and consumer sovereignty simultaneously (Table 2). Implementing sustainable food systems takes time and resources, yet such an effort can be seen as an investment for future sustainability and independence. The willingness to contribute to such a transition depends substantially upon existing resources, goodwill, and the education of consumers and producers. To increase cooperation for such a transition, civil society will need training, control over the means of production, and adequate information. The failure to provide such means will affect significantly the willingness of people to align their consumption patterns and production methods so that the aims for sovereignty as consumers and producers can stand in a constructive relation with each other.

In terms of synergies between the two aims for sovereignty, consumers who are better aware of the environmental and social costs of food production can do their share in supporting farmers fairly and do their part in absorbing seasonal production variability. Yet to secure the 
compatibility of both aims, producers and consumers should be informed about the broadness of the concept of autonomy and be taught that self-constraint does not mean necessarily a loss of rights as part of a campaign to increase political literacy. This will take major public education campaigns that not only involve information on the food production systems that are socially and environmentally superior alternatives, but also in the normative understanding of concepts such as fairness, autonomy, empowerment, and sustainability. Such efforts can be combined with projects to increase literacy of political concepts that are in much need to safeguard democratic institutions.

It is noteworthy that both the aims for food sovereignty and consumer sovereignty do not embrace a traditional social-democratic state or a neoliberal market model. As people-centered approaches neither big business nor the state are perceived as the precursor for sovereignty, it is people acting constructively as individuals and as collectives that have the power to claim sovereignty.

Acknowledgments: We wish to thank Antonio Castellanos-Navarrete, Nelson Álvarez Febles, the participants of seminars in Salzburg, Vienna and Wageningen, and two anonymous reviewers, who enriched the writing process by providing valuable feedback on earlier versions of the paper.

Funding: CT received funding from the DGAPA-UNAM (Universidad Nacional Autónoma de México) post-doctoral fellowship program and the Austrian Academy of Sciences visiting fellowship program during the initial stages of this study. GF receives funding by the European Union ERA-ARD-II Woody Amendments for Sudano-Sahelian Agroecosystems (WASSA) research project. The disclosed institutions employ the respective authors.

\section{References}

Agarwal, Bina. 2014. "Food sovereignty, food security and democratic choice: Critical contradictions, difficult conciliations." Journal of Peasant Studies no. 41 (6):1247-1268.

Altieri, Miguel A. 2002. "Agroecological Principles for Sustainable Agriculture." In Agroecological Innovations: Increasing Food Production with Participatory Development, edited by Norman Uphoff, 40-46. London \& Sterling, VA: Earthscan.

Altieri, Miguel A, Nelso Companioni, Kristina Cañizares, Catherine Murphy, Peter Rosset, Martin Bourque, and Clara I Nicholls. 1999. "The greening of the "barrios": urban agriculture for food security in Cuba." Agriculture and Human Values no. 16 (2):131-140.

Altieri, Miguel A, Clara I Nicholls, Alejandro Henao, and Marcos A Lana. 2015. "Agroecology and the design of climate change-resilient farming systems." Agronomy for Sustainable Development:122.

Altieri, Miguel A, and Victor Manuel Toledo. 2011. "The agroecological revolution in Latin America: rescuing nature, ensuring food sovereignty and empowering peasants." Journal of Peasant Studies no. 38 (3):587-612.

Beekman, Volkert. 2008. "Consumer rights to informed choice on the food market." Ethical Theory and Moral Practice no. 11 (1):61-72.

Bernstein, Henry. 2014. "Food sovereignty via the 'peasant way': a sceptical view." Journal of Peasant Studies no. 41 (6):1031-1063. doi: 10.1080/03066150.2013.852082. 
Beuchelt, Tina D, and Detlef Virchow. 2012. "Food sovereignty or the human right to adequate food: which concept serves better as international development policy for global hunger and poverty reduction?" Agriculture and Human Values no. 29 (2):259-273.

Beyranevand, Laurie J. 2012. "Forging Toward Coexistence." Nebraska Law Review no. 91:767-804.

Borras Jr, Saturnino M, Jennifer C Franco, and Sofía Monsalve Suárez. 2015. "Land and food sovereignty." Third World Quarterly no. 36 (3):600-617.

Burgess, JA, and Adrian J Walsh. 1999. "Consumer Sovereignty, Rationality and the Mandatory Labelling of Genetically Modified Food." Business \& Professional Ethics Journal no. 18 (3/4):726.

Christman, John. 2015. Autonomy in moral and political philosophy. In Stanford Encyclopedia of Philosophy (Spring 2015 edition), edited by Edward N. Zalta.

Coff, Christian, Michiel Korthals, and David Barling. 2008. "Ethical traceability and informed food choice." In Ethical traceability and communicating food, edited by Christian Coff, David Barling, Michiel Korthals and Thorkild Nielsen, 1-18. Dordrecht: Springer.

Consulta de los Pueblos Indígenas sobre el Derecho a la Alimentación. 2002. Declaración de Atitlán. Panajachel.

Coolsaet, Brendan. 2015. "Transformative Participation in Agrobiodiversity Governance: Making the Case for an Environmental Justice Approach." Journal of Agricultural and Environmental Ethics no. 28 (6):1089-1104.

Dar, William D, and CL Laxmipathi Gowda. 2013. "Declining agricultural productivity and global food security." Journal of Crop Improvement no. 27 (2):242-254.

de Grammont, Hubert Carton. 2008. "Fortalezas y debilidades de la organización campesina en el contexto de la transición política." El Cotidiano no. 147:43-50.

De Schutter, Olivier. 2011. The right to an adequate diet: The agriculture-food-health nexus, Report presented at the 19th Session of the United Nations Human Rights Council (A/HRC/19/59). Geneva: United Nations.

de Wit, Maywa Montenegro, and Alastair Iles. 2016. "Toward thick legitimacy: Creating a web of legitimacy for agroecology." Elementa: Science of the Anthropocene no. 4 (1):000115.

de-Shalit, Avner. 2004. "Political philosophy and empowering citizens." Political Studies no. 52 (4):802818.

Dehnen-Schmutz, Katharina, Gemma L Foster, Luke Owen, and Séverine Persello. 2016. "Exploring the role of smartphone technology for citizen science in agriculture." Agronomy for Sustainable Development no. 36 (2):1-8.

Del Savio, Lorenzo, and Bettina Schmietow. 2013. "Environmental footprint of foods: The duty to inform." Journal of Agricultural and Environmental Ethics no. 26 (4):787-796.

Delgado Ramos, Gian Carlo. 2013. "Cambio climático y la alimentación de las ciudades." Investigación ambiental Ciencia y política pública no. 5 (1):76-93.

Devin, Bree, and Carol Richards. 2016. "Food Waste, Power, and Corporate Social Responsibility in the Australian Food Supply Chain." Journal of Business Ethics:1-12.

Dixon, Beth A. 2014. "Learning to see food justice." Agriculture and Human Values no. 31 (2):175-184.

Dumont, Antoinette M, Gaëtan Vanloqueren, Pierre M Stassart, and Philippe V Baret. 2016. "Clarifying the socioeconomic dimensions of agroecology: between principles and practices." Agroecology and Sustainable Food Systems no. 40 (1):24-47.

Edelman, Marc. 2014. "Food sovereignty: Forgotten genealogies and future regulatory challenges." Journal of Peasant Studies no. 41 (6):959-978.

FAO. 2015. FAO Statistical Pocketbook 2015. Rome: Food and Agriculture Organization of the United Nations.

Food Ethics Council. 2010. Food Justice: the report of the Food and Fairness Inquiry. Brighton: Food Ethics Council.

Fridell, Gavin. 2009. "The co-operative and the corporation: Competing visions of the future of fair trade." Journal of Business Ethics no. 86 (1):81-95. 
Friel, Sharon, and Laura Ford. 2015. "Systems, food security and human health." Food Security no. 7 (2):437-451.

Frison, E. 2016. From uniformity to diversity: a paradigm shift from industrial agriculture to diversified agroecological systems: International Panel of Experts on Sustainable Food systems.

Funes-Monzote, F., Miguel A. Altieri, and Peter Rosset. The Avery diet: the Hudson Institute's misinformation campaign against Cuban agriculture 2009. Available from http://globalalternatives.org/files/AveryCubaDiet.pdf.

Gebbers, Robin, and Viacheslav I. Adamchuk. 2010. "Precision agriculture and food security." Science no. 327 (5967):828-831.

Gilson, Erinn Cunniff. 2015. "Vulnerability, Relationality, and Dependency: Feminist Conceptual Resources for Food Justice." IJFAB: International Journal of Feminist Approaches to Bioethics no. 8 (2):10-46.

Gjerris, Mickey, Christian Gamborg, and Henrik Saxe. 2016. "What to Buy? On the Complexity of Being a Critical Consumer." Journal of Agricultural and Environmental Ethics no. 29 (1):81-102.

Gliessman, Stephen R. 2002. Agroecología: procesos ecológicos en agricultura sostenible. Turrialba: Centro Agronómico Tropical de Investigación y Enseñanza (CATIE). 2007. Agroecology: the ecology of sustainable food systems. Boca Raton: CRC Press.

Godfray, H Charles J, John R Beddington, Ian R Crute, Lawrence Haddad, David Lawrence, James F Muir, Jules Pretty, Sherman Robinson, Sandy M Thomas, and Camilla Toulmin. 2010. "Food security: the challenge of feeding 9 billion people." Science no. 327 (5967):812-818.

Grey, Sam, and Raj Patel. 2015. "Food sovereignty as decolonization: some contributions from Indigenous movements to food system and development politics." Agriculture and Human Values no. 32 (3):431-444.

Hansen, Ursula, and Ulf Schrader. 1997. "A modern model of consumption for a sustainable society." Journal of Consumer Policy no. 20 (4):443-468.

Hassanein, Neva. 2003. "Practicing food democracy: a pragmatic politics of transformation." Journal of Rural Studies no. 19 (1):77-86.

Hassoun, Nicole. 2009. "Free trade and the environment." Environmental Ethics no. 31 (1):51-66.

- 2015. "The ethics of consumption and non-consumption."." In The Routledge Handbook of Global Ethics, edited by Darrel Moellendorf and Heather Widdows, 267-278. London \& New York: Routledge.

Holt-Giménez, Eric. Boricuá: Agroecology and the return of family farming in Puerto Rico. Food First 2013 [cited October 4, 2016. Available from http://foodfirst.org/boricua-agroecology-and-thereturn-of-family-agriculture-in-puerto-rico/.

Hospes, Otto. 2014. "Food sovereignty: the debate, the deadlock, and a suggested detour." Agriculture and Human Values no. 31 (1):119-130.

Howlett, Elizabeth, Cassandra Davis, and Scot Burton. 2015. "From Food Desert to Food Oasis: The Potential Influence of Food Retailers on Childhood Obesity Rates." Journal of Business Ethics. doi: 10.1007/s10551-015-2605-5.

Iles, Alastair. 2005. "Learning in sustainable agriculture: food miles and missing objects." Environmental Values no. 14 (2):163-183.

Iles, Alastair, and Robin Marsh. 2012. "Nurturing diversified farming systems in industrialized countries: how public policy can contribute." Ecology and society no. 17 (4):42.

Jellema, Andre, Wouter Meijninger, and Chris Addison. 2015. Open data and smallholder food and nutritional security: CTA Working Paper 15/01.

Jensen, Robert. 2007. "The digital provide: Information (technology), market performance, and welfare in the South Indian fisheries sector." The quarterly journal of economics:879-924.

Johnson, Jeffrey Alan. 2014. "From open data to information justice." Ethics and Information Technology no. $16(4): 263-274$. 
Kalfagianni, Agni. 2014. "Addressing the global sustainability challenge: The potential and pitfalls of private governance from the perspective of human capabilities." Journal of Business Ethics no. $122(2): 307-320$.

Kallhoff, Angela. 2014. "Water Justice: A Multilayer Term and Its Role in Cooperation." Analyse \& Kritik no. 36 (2):367-382.

Kates, Michael. 2015. "The Ethics of Sweatshops and the Limits of Choice." Business Ethics Quarterly no. 25 (2):191-212. doi: 10.1017/beq.2015.9.

Kloppenburg, Jack. 2014. "Re-purposing the master's tools: the open source seed initiative and the struggle for seed sovereignty." Journal of Peasant Studies no. 41 (6):1225-1246. doi: 10.1080/03066150.2013.875897.

Konstantinidis, Charalampos. 2016. "The Neoliberal Restructuring of Agriculture and Food in Greece." Review of Radical Political Economics. doi: 10.1177/0486613416655454.

Korthals, Michiel. 2001. "Taking consumers seriously: Two concepts of consumer sovereignty." Journal of Agricultural and Environmental Ethics no. 14 (2):201-215.

- 2004. Before Dinner: Philosophy and Ethics of Food. Dordrecht: Springer.

Lappé, Frances Moore, Jennifer Clapp, Molly Anderson, Robin Broad, Ellen Messer, Thomas Pogge, and Timothy Wise. 2013. "How we count hunger matters." Ethics \& International Affairs no. 27 (03):251-259.

Larsen, Gretchen, and Rob Lawson. 2013. "Consumer rights: an assessment of justice." Journal of Business Ethics no. 112 (3):515-528.

LeBrón, Marisol. 2016. "People Before Debt: Puerto Ricans confront the island's debt crisis "from below."." NACLA Report on the Americas no. 48 (2):115-117.

Lee, Richard Philip. 2013. "The politics of international agri-food policy: discourses of trade-oriented food security and food sovereignty." Environmental Politics no. 22 (2):216-234.

Leff, Enrique. 1986. "Ecotechnological productivity: a conceptual basis for the integrated management of natural resources." Social Science Information no. 25 (3):681-702.

Lessmann, Ortrud, and Felix Rauschmayer. 2013. "Re-conceptualizing sustainable development on the basis of the capability approach: A model and its difficulties." Journal of Human Development and Capabilities no. 14 (1):95-114.

Loo, Clement. 2014. "Towards a More Participative Definition of Food Justice." Journal of Agricultural and Environmental Ethics no. 27 (5):787-809.

Macfadyen, Sarina, Jason M. Tylianakis, Deborah K. Letourneau, Tim G. Benton, Pablo Tittonell, Michael P. Perring, Carla Gómez-Creutzberg et al. 2015. "The role of food retailers in improving resilience in global food supply." Global Food Security no. 7: 1-8.

Martínez-Torres, María Elena, and Peter M Rosset. 2014. "Diálogo de saberes in La Vía Campesina: food sovereignty and agroecology." Journal of Peasant Studies no. 41 (6):979-997.

McIntyre, Beverly D., Hans R. Herren, Judi Wakhungu, and Robert T. Watson. 2009. International assessment of agricultural knowledge, science and technology for development (IAASTD): synthesis report with executive summary: a synthesis of the global and sub-global IAASTD reports. Washington, DC: Island Press.

McIvor, David W, and James Hale. 2015. "Urban agriculture and the prospects for deep democracy." Agriculture and Human Values no. 32 (4):727-741.

Medland, Lydia. 2016. "Working for social sustainability: insights from a Spanish organic production enclave." Agroecology and Sustainable Food Systems no. 40 (10):1133-1156.

Méndez, V Ernesto, Christopher M Bacon, and Roseann Cohen. 2013. "Agroecology as a transdisciplinary, participatory, and action-oriented approach." Agroecology and Sustainable Food Systems no. 37 (1):3-18.

Menser, Michael. 2008. "Transnational participatory democracy in action: The case of La Via Campesina." Journal of Social Philosophy no. 39 (1):20-41. 
Messer, Ellen. 2009. "Rising food prices, social mobilizations, and violence: conceptual issues in understanding and responding to the connections linking hunger and conflict." Napa Bulletin no. $32(1): 12-22$.

Nicholls, Clara Inés, Miguel A Altieri, and L Vazquez. 2016. "Agroecology: Principles for the Conversion and Redesign of Farming Systems." Journal of Ecosystem \& Ecography no. S5:010.

Nyéléni Forum. 2015. International Forum for Agroecology Sélingué: Nyéléni Center.

Nyéléni Forum for Food Sovereignty. 2007. Declaration of Nyéléni. Sélingue: Nyéléni Forum for Food Sovereignty.

Oxfam America. 2004. Like machines in the fields: Workers without rights in American agriculture. Boston: Oxfam America.

Paes-Sousa, Romulo, and Jeni Vaitsman. 2014. "The Zero Hunger and Brazil without Extreme Poverty programs: a step forward in Brazilian social protection policy." Ciência \& Saúde Coletiva no. 19 (11):4351-4360.

Paré, Luisa. 2010. "La relación campo-ciudad: elementos para agendas en común." Revista ALASRU no. 5:95-103.

Power, Alison G. 2010. "Ecosystem services and agriculture: tradeoffs and synergies." Philosophical Transactions of the Royal Society of London B: Biological Sciences no. 365 (1554):2959-2971.

Raynolds, Laura T. 2014. "Fairtrade, certification, and labor: global and local tensions in improving conditions for agricultural workers." Agriculture and Human Values no. 31 (3):499-511. doi: 10.1007/s10460-014-9506-6.

Rehman, F, S Muhammad, I Ashraf, K Mahmood Ch, and T Ruby. 2013. "Effect of farmers' socioeconomic characteristics on access to agricultural information: Empirical evidence from Pakistan." The Journal of Animal \& Plant Sciences no. 23 (1):324-329.

Rivera, Faviola. 2006. "Kantian ethical duties." Kantian Review no. 11:78-101.

Rosset, Peter. 2009. "Fixing our global food system: Food sovereignty and redistributive land reform." Monthly Review no. 61 (3):114-128.

Ruf, François, Götz Schroth, and Kone Doffangui. 2015. "Climate change, cocoa migrations and deforestation in West Africa: What does the past tell us about the future?" Sustainability Science no. 10 (1):101-111.

Rundgren, Gunnar. 2016. "Food: From Commodity to Commons." Journal of Agricultural and Environmental Ethics no. 29 (1):103-121.

Rydin, Yvonne, Ana Bleahu, Michael Davies, Julio D Dávila, Sharon Friel, Giovanni De Grandis, Nora Groce, Pedro C Hallal, Ian Hamilton, and Philippa Howden-Chapman. 2012. "Shaping cities for health: complexity and the planning of urban environments in the 21 st century." The Lancet no. 379 (9831):2079-2108.

Sarandón, Santiago Javier, and Claudia Cecilia Flores. 2014. Agroecología: bases teóricas para el diseño y manejo de agroecosistemas sustentables. La Plata: Editorial de la Universidad Nacional de La Plata.

Schipanski, Meagan E, Graham K MacDonald, Steven Rosenzweig, M Jahi Chappell, Elena M Bennett, Rachel Bezner Kerr, Jennifer Blesh, Timothy Crews, Laurie Drinkwater, and Jonathan G Lundgren. 2016. "Realizing Resilient Food Systems." BioScience no. 66 (7):600-610.

Shattuck, Annie, Christina M Schiavoni, and Zoe VanGelder. 2015. "Translating the Politics of Food Sovereignty: Digging into Contradictions, Uncovering New Dimensions." Globalizations no. 12 (4):421-433.

Shebaya, Sirine. 2009. "Global and Local Sovereignties." Public Reason no. 1 (1):125-140.

Shiva, Vandana. 2009. "Women and the gendered politics of food." Philosophical Topics no. 37 (2):1732.

Smith, Andrew F. 2016. "Food Deserts, Capabilities, and the Rectification of Democratic Failure." Journal of Human Development and Capabilities no. 17 (2):178-190.

Szende, Jennifer. 2015. "Food Deserts, Justice, and the Distributive Paradigm." In Just Food: Philosophy, Justice, and Food, edited by J. M. Dieterle, 57-68. London: Rowman and Littlefield. 
Tencati, Antonio, and Laszlo Zsolnai. 2012. "Collaborative enterprise and sustainability: The case of slow food." Journal of Business Ethics no. 110 (3):345-354.

Thi, Ngoc Bao Dung, Gopalakrishnan Kumar, and Chiu-Yue Lin. 2015. "An overview of food waste management in developing countries: current status and future perspective." Journal of environmental management no. 157:220-229.

Thompson, Paul B. 2015a. From field to fork: Food ethics for everyone. New York: Oxford University Press.

- 2015b. "From world hunger to food sovereignty: food ethics and human development." Journal of Global Ethics no. 11 (3):336-350.

Timmermann, Cristian, and Georges F. Félix. 2015. "Agroecology as a vehicle for contributive justice." Agriculture and human values no. 32 (3): 523-538.

Timmermann, Cristian, and Zoë Robaey. 2016. "Agrobiodiversity under different property regimes." Journal of Agricultural and Environmental Ethics no. 29 (2): 285-303.

Tittonell, Pablo. 2013. Farming Systems Ecology: Towards Ecological Intensification of World Agriculture. Wageningen: Wageningen Universiteit.

Tittonell, Pablo 2016. Feeding the world with soil science: embracing sustainability, complexity and uncertainty. SOIL Discuss, doi: 10.5194/soil-2016-7

Tittonell, Pablo, Klerkx, Laurens, Baudron, Frederic, Félix, Georges F., Ruggia, Andrea, van Apeldoorn, Dirk, et al. 2016. Ecological Intensification: Local Innovation to Address Global Challenges. Sustainable Agriculture Reviews, 19, 1-34.

Toledo, Victor M. and Narciso Barrera-Bassols. 2008. La memoria biocultural. Barcelona: Icaria.

Turner, Bethaney, Joanna Henryks, and David Pearson. 2011. "Community gardens: sustainability, health and inclusion in the city." Local Environment no. 16 (6):489-492.

UN Committee on Economic Social and Cultural Rights. 1999. General comment 12. The right to adequate food (article 11) (E/C.12/1999/5). Geneva: United Nations Economic and Social Council.

UNCTAD. 2013. Least Developed Countries Report 2013 - Growth with employment for inclusive and sustainable development. New York and Geneva: United Nations.

Underhill, Elsa, Dimitria Groutsis, Diane van den Broek, and Malcolm Rimmer. 2016. "Migration Intermediaries and Codes of Conduct: Temporary Migrant Workers in Australian Horticulture." Journal of Business Ethics. doi: 10.1007/s10551-016-3351-z.

Van der Ploeg, Jan Douwe. 2014. "Peasant-driven agricultural growth and food sovereignty." Journal of Peasant Studies no. 41 (6):999-1030.

Via Campesina. 1996. The right to produce and access land. Rome: Via Campesina.

Walton, Andrew. 2014. "Do Moral Duties Arise from Global Trade?" Moral Philosophy and Politics no. 1 (2):249-268.

Werkheiser, Ian, and Zachary Piso. 2015. "People work to sustain systems: A framework for understanding sustainability." Journal of Water Resources Planning and Management no. 141 (12):A4015002.

Wittman, Hannah, Michael Jahi Chappell, David James Abson, Rachel Bezner Kerr, Jennifer Blesh, Jan Hanspach, Ivette Perfecto, and Joern Fischer. 2016. "A social-ecological perspective on harmonizing food security and biodiversity conservation." Regional Environmental Change:1-11.

World Food Program. Who are the hungry? 2015 [cited November 2, 2016. Available from https://http://www.wfp.org/hunger/who-are.

Ziegler, Jean. 2011. Destruction massive: Géopolitique de la faim. Paris: Seuil. 